\title{
OPTIMASI JARINGAN 4G LTE (LONG TERM EVOLUTION) PADA KOTA BALIKPAPAN
}

\author{
Maria Ulfah ${ }^{1}$, Andi Sri Irtawaty ${ }^{2}$ \\ ${ }^{1,2}$ Jurusan Teknik Elektronika, Politeknik Negeri Balikpapan \\ ${ }^{1}$ maria.ulfah@poltekba.ac.id
}

\begin{abstract}
Long Term Evolution (LTE) is a fourth generation (4G) technology developed by the 3rd Generation Partnership Project (3GPP). LTE is capable of providing downlink speeds of up to 100 Mbps and 50 Mbps uplink. This research has a purpose to do $4 G$ LTE network design in Balikpapan city with a specific target to determine the quality of 4G LTE network design in Balikpapan city through the best signal level, $C /(N+I)$, throughput, RSRP and BLER parameters from the design have been done. The research method was conducted through a survey to the locations of e Node sites needed to obtain a direct picture of the conditions around e Node B followed by plotting 126 e Node B sites in the city of Balikpapan and then proceeding with the network design simulation using Atoll software. From the results of this simulation can be known the quality of the 4G LTE network design in Balikpapan city with the desired parameter values such as best signal level of $-69,72 \mathrm{dBm}, \mathrm{C} /(\mathrm{N}+\mathrm{I})$ value of 5,08 . For throughput performance is $11.8034 \mathrm{kbps}$, while the RSRP value is $-115,88 \mathrm{dBm}$ and the BLER value is 0,03 .
\end{abstract}

Keywords : 4G, LTE. e Node B , RSRP, C/ (N+I)

\section{INTISARI}

Long Term Evolution (LTE) merupakan teknologi generasi ke empat (4G) yang dikembangkan oleh 3rd Generation Partnership Project (3GPP). LTE mampu memberikan kecepatan downlink sampai dengan 100 Mbps dan uplink 50 Mbps. Penelitian ini mempunyai tujuan untuk melakukan perancangan jaringan 4G LTE pada wilayah kota Balikpapan dengan target khusus untuk mengetahui kualitas perancangan jaringan 4G LTE di kota Balikpapan melalui parameter best signal level, nilai $\mathrm{C} /(\mathrm{N}+\mathrm{I})$, throughput, RSRP dan BLER dari perancangan yang telah dilakukan. Metode penelitian dilakukan melaui survey ke lokasi site-site e Node yag diperlukan untuk memperoleh gambaran langsung kodisi sekitar e Node B dilanjutkan proses plotting 126 sitesite e Node B di wilayah kota Balikpapan kemudian yang dilanjutkan dengan proses simulasi perancangan jaringan menggunakan software Atoll. Dari hasil simulasi ini dapat diketahui kualitas perancangan jaringan 4G LTE kota Balikpapan dengan nilai-nilai parameter yang diinginkan seperti best signal level sebesar $-69,72$ $\mathrm{dBm}$, nilai $\mathrm{C} /(\mathrm{N}+\mathrm{I})$ sebesar 5,08. Untuk perfomansi throughput sebesar $11.8034 \mathrm{kbps}$, sedangkan nilai RSRP sebesar $-115,88 \mathrm{dBm}$ serta nilai BLER sebesar 0,03 .

Kata kunci: 4G, LTE. e Node B , RSRP, C/ (N+I)

\section{PENDAHULUAN}

Perkembangan jaringan telekomunikasi saat ini semakin berkembang dengan sangat pesat. Yang pada awalnya hanya mengusung teknologi analog atau yang lebih dikenal dengan $1 \mathrm{G}$ atau Advanced Mobile Phone Service (AMPS), kemudian berkembang lagi ke teknologi yang menggunakan teknologi digital pertama (2G), kemudian teknologi $2 \mathrm{G}$ sebelumnya dikembangkan lagi sehingga kecepatan transfer datanya semakin cepat yang dikenal dengan teknologi digital generasi ketiga (3G) dan sampai akhirnya ditemukan teknologi komunikasi dengan kecepatan yang sangat tinggi dari generasi - generasi sebelumnya yang lebih dikenal 
dengan sebutan 4G/LTE ( Long Term Evolution ).

Kebutuhan para pengguna smartphone remaja ini sangat menginginkan akses mobile data yang sangat banyak. Selain melalui smartphone, penggunaan Personal Computer (PC) maupun tablet sangat mendorong pertumbuhan konsumsi mobile data. Teknologi LTE (Long Term Evolution) sendiri menawarkan kecepatan downlink hingga 100 Mbps dan Uplink hingga 50 Mbps.

4G sendiri adalah singkatan dalam bahasa Inggris : Fourth Generation. Istilah ini umumnya digunakan mengacu kepada standar generasi keempat dari teknologi telpon seluler yang merupakan pengembangan dari teknologi sebelumnya yaitu $2 \mathrm{G}$ dan $3 \mathrm{G}$. Sistem $4 \mathrm{G}$ merupakan sebuah sistem yang mampu menjembatani antar berbagai jaringan broadband wireless access yang telah ada di masyarakat secara seamlessly (tidak terasa proses perpindahan antar jaringan yang sedang digunakan) baik itu perangkatnya, jaringannya, maupun aplikasinya.

Dikarenakan belum ratanya jaringan 4G/LTE di kota Balikpapan maka dibutuhkanlah suatu perancangan jaringan 4G LTE agar semua pengguna smartphone di Balikpapan khususnya dapat merasakan teknologi ini. Pada Maharani [5] melakukan penelitian untuk menentukan jumlah E Node B kecamatan Balikpapan Timur. Dalam Maria [6] didapatkan jumlah E node B untuk kota Balikpapan meliputi 6 kecamatan yang ada sejumlah 126, sehingga dalam penelitian ini akan dilakukan pengamatan lebih lanjut mengenai coverage area jaringan 4G LTE untuk kota Balikpapan dengan itu penulis mengangkat judul penelitian sebagai berikut yaitu: "Optimasi Jaringan 4G LTE (Long Term Evolution) pada Kota Balikpapan “

\section{LANDASAN TEORI}

\section{A. Four Generation LTE (4G LTE)}

Long term Evolution (LTE) adalah jaringan akses radio evolusi jangka panjang keluaran dari 3rd Generation Partership Project (GPP). LTE merupakan kelanjutan dari teknologi generasi ketiga (3G) WDCMA-UMTS. Teknologi ini telah sukses diuji cobakan secara komersial sejak tahun 2009 dan diharap menjadi standar evolusi komunikasi data pita lebar bergerak untuk dasawarsa mendatang. Semenjak Desember 2007, 3GGP melakukan studi kelayakan untuk LTE dengan mengeluarkan Release-7. Akhirnya konsep LTE terbentuk pada 2008 dengan dikeluarkannya Realase-8.

Pada LTE kecepatan transfer data mencapai 100Mbps pada sisi downlink dan 50Mbps pada sisi uplink. Berikut adalah gambar yang menunjukkan perkembangan 3GPP dari release 99 hingga release 8 [6]

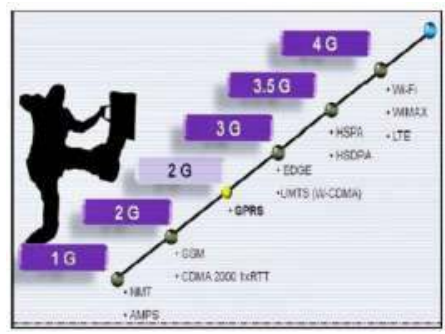

Gambar 1. Perkembangan Teknologi Seluler

Tabel 1. Evolusi Teknologi Telekomunikasi Seluler

\begin{tabular}{|c|c|c|c|c|}
\hline & $\begin{array}{c}\text { WDCMA } \\
\text { (UTMS) }\end{array}$ & HSPA & HSPA+ & LTE \\
\hline Downlink MexSpeed (bps) & $384 \mathrm{k}$ & $14 \mathrm{~m}$ & $28 \mathrm{~m}$ & $100 \mathrm{~m}$ \\
\hline $\begin{array}{c}\text { Uplink MexSpeed (bps) } \\
\text { Latency-RTI }\end{array}$ & $128 \mathrm{k}$ & $5.7 \mathrm{~m}$ & $11 \mathrm{~m}$ & $5 \mathrm{~m}$ \\
\hline 3GPP Release & $150 \mathrm{~ms}$ & $100 \mathrm{~ms}$ & $50 \mathrm{~ms}$ & $\sim 10 \mathrm{~ms}$ \\
\hline $\begin{array}{c}\text { Access } \\
\text { Methodologi }\end{array}$ & CDMA & CDMA & CDMA & $\begin{array}{c}\text { OFDMA } / 4 \mathrm{SC}- \\
\text { FDMA }\end{array}$ \\
\hline
\end{tabular}




\section{B. Arsitektur Jaringan $4 G$ LTE}

Berikut arsitektur jaringan 4G LTE

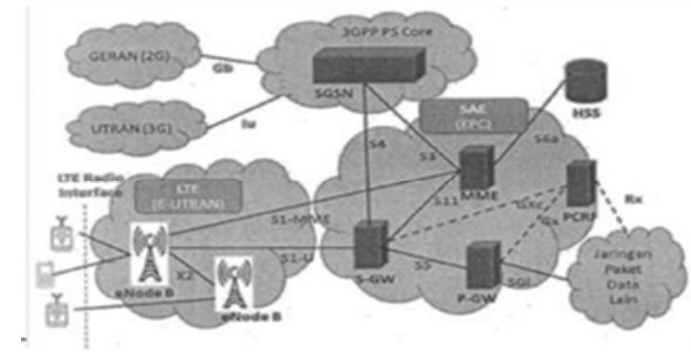

Gambar 2. Arsitektur 4G LTE

Arsitektur LTE [7] terdiri atas dua bagian utama yakni LTE itu sendiri yang dikenal juga dengan E-UTRAN (Envolved Universal Terrestrial Radio Access Network) dan SAE (System Architecture Evolution ) yang merupakan jantung dari sistem LTE. Berikut ini adalah penjelasan masing-masing bagian dari arsitektur LTE diatas:

\section{Bagian Akses Radio (LTE):}

a) UE (User Equipment), adalah perangkat komunikasi pengguna. perangkat ini dapat berupa telepon genggam, komputer, tablet, maupun segala perangkat cerdas yang dapat terhubung dengan internet.

b) eNodeB (envolved NodeB) adalah antar-muka jaringan (LTE) dengan pengguna. kemampuannya untuk melakukan fungsi kontrol sambungan dan handover.

2. Bagian sentral (SAE)

a) S-GW (Serving Gateway), betugas mengatur jalan dan meneruskan data yang berupa paket dari setiap UE. S-GW berfungsi sebagai penghubung antara LTE dengan teknologi 3GPP lainnya seperti GSM/EDGE Radio Access Network (GERAN) dan UTMS
Terrestrial Radio Access Network (UTRAN)

b) P-GW (Packet Data Network Gateway), bertugas mengatur hubungan jaringan data antara UE dengan jaringan paket data lain diluar 3GPP seperti WLAN, Wimax

c) MME (Mobility Management Entity), merupakan pengatur utama setiap bagian dari LTE/SAE. Pada saat UE tidak aktif, MME bertugas untuk melacak keberadaan pelanggan dengan melakukan tracking dan paging. Saat UE aktif, MME berfungsi bertugas untuk memilihkan S-GW yang tepat selama berlangsungnya komunikasi.

3. PCRF (Policy and Charging Rules Function), berfungsi menentukan Quality of Service (QoS) dan charging untuk masing-masing UE.

4. HSS (Home Subscriber Server), berupa sistem database yang bertugas membantu MME dan melakukan manajemen pelanggan dan pengamanan. Penerimaan atau penolakan UE pada saat autentikasi bergantung pada database HSS.

\section{Parameter Perfomansi Jaringan $4 G$ LTE}

Berikut parameter-parameter perfomansi jaringan 4G LTE :

1. RSSI ( Received Signal Strength Indicator )

Merupakan power sinyal yang diterima user dalam rentang frekuensi tertentu termasuk noise dan interferensi (disebut juga wideband power) sering juga disebut signal level [4] 
Tabel 2. Rentang nilai RSSI (signal level) [3]

\begin{tabular}{|ll|}
\hline \multicolumn{1}{|c|}{ RSSI } & \multicolumn{1}{c|}{ Signal Strength } \\
\hline $7.70 \mathrm{dBm}$ & Excellent \\
\hline $.70 \mathrm{dBm}$ to $-85 \mathrm{dBm}$ & Good \\
\hline $.86 \mathrm{dBm}$ to $-100 \mathrm{dBm}$ & Fair \\
\hline$-100 \mathrm{dBm}$ & Poor \\
$110 \mathrm{dBm}$ & No signal \\
\hline
\end{tabular}

2. $\mathrm{C} /(\mathrm{N}+\mathrm{I})$, Carrier to Noise Interferensi Ratio

Merupakan rasio perbandingan antara sinyal utama yang dipancarkan dengan interferensi dan noise yang timbul (tercampur dengan sinyal utama) [4]

Tabel 3. Rentang Nilai C/(N+I) [3]

\begin{tabular}{|ll|}
\hline \multicolumn{1}{|c|}{ SINR Value } & \multicolumn{1}{c|}{ Throughput } \\
\hline 10 & Excellent \\
\hline 6 to 10 & Good \\
0 to 5 & fair \\
\hline 0 & Poor \\
\hline
\end{tabular}

3. RSRP (Reference Signal Received Power)

Merupakan sinyal LTE power yang diterima oleh user dalam frekuensi tertentu. Semakin jauh jarak antara site dan user, maka semakin kecil pula RSRP yang diterima oleh user

Tabel 4. Rentang Nilai RSRP [3]

\begin{tabular}{|l|l|}
\hline \multicolumn{1}{|c|}{ RSRP } & \multicolumn{1}{c|}{ Signal Strength } \\
\hline$>-90 \mathrm{dBm}$ & Excellent \\
\hline$-90 \mathrm{dBm}$ to $-105 \mathrm{dBm}$ & Good \\
\hline$-106 \mathrm{dBm}$ to $-120 \mathrm{dBm}$ & Fair \\
\hline$<-120 \mathrm{dBm}$ & Poor \\
\hline
\end{tabular}

\section{Throughput}

Throughput merupakan besaran kecepatan akses data yang didapat oleh user.

\section{BLER (Block Eror Rate)}

Merupakan rasio perbandingan antara total error block dengan total block dari sebuah transmisi data digital. BLER digunakan untuk mengetahui tingkat keberhasilan dari demodulasi sinyal. BLER masih dianggap baik apabila bernilai $<10 \%$. semakin besar nilai BLER mengakibatkan gagal demodulasi data digital menjadi informasi.[3]

D. Atoll [2]

Atoll adalah model dan optimasi program multi teknologi jaringan yang berskala dan fleksibel yang mendukung keseluruhan jaringan wireless operator dari model awal untuk proses perancangan dan optimasi. Atoll juga merupakan sistem informasi terbuka yang mudah terhubung dengan aplikasi IT yang lain dan meningkatan produktivitas.

Atoll mendukung GSM / GPRS / EDGE, UMTS / HSPA, LTE, CDMA20001xRTT/EV-DO, TD-SCDMA, WiMAX dan Link Microwave. Modul Atoll LTE adalah alat perencanaan jaringan pertama yang tersedia di pasaran. Atoll telah digunakan untuk pengerjaan projek jaringan di seluruh dunia.

\section{METODE PENELITIAN}

\section{A. Rancangan Penelitian}

Rancangan penelitian merupakan keseluruhan proses penelitian dari awal hingga tahap akhir, dan disajikan dalam bentuk flowchart 


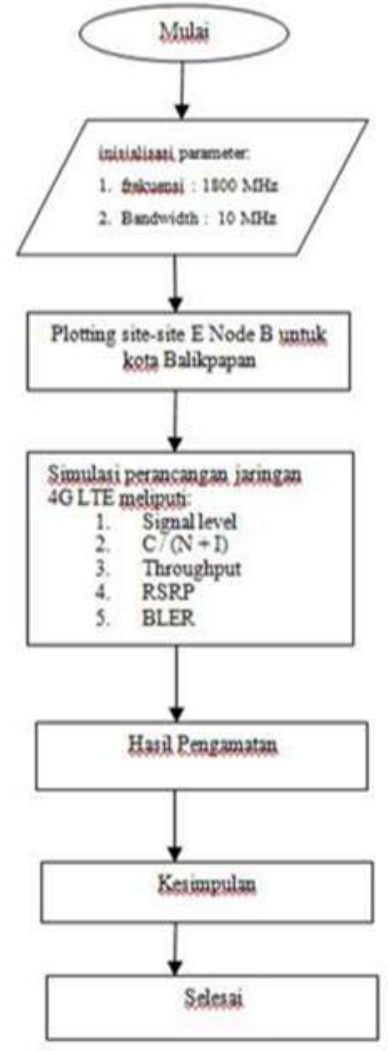

Gambar 3. Flowchart

B. Teknik Pengumpulan dan Analisis Data

Teknik Pengumpulan data dilakukan dengan RF Site survey untuk penentuan lokasi-lokasi yang potensial dilanjutkan dengan plotting sejumlah e Node B tersebut pada perangkat lunak perancangan jaringan 4G LTE dilanjutkan dengan melakukan simulasi perancangan jaringan 4G LTE dengan mengamati nilai parameter signal level, C / $(\mathrm{N}+\mathrm{I})$, throughput, RSRP dan BLER. Kemudian dilanjutkan membuat kesimpulan terhadap hasil perancangan jaringan tersebut

\section{HASIL PENELITIAN DAN PEMBAHASAN}

.Untuk penentuan wilayah-wilayah penempatan lokasi E Node B dilakukan dengan cara survey ke lapangan (RF
Survey) untuk mendapatkan lokasi longtitude dan latitude yang nanti akan dilanjutkan dengan proses plotting plotting sejumlah site-site E node B pada software perancangan jaringan 4G LTE yakni Atoll

Tabel 5. Data E Node B Kota Balikpapan

\begin{tabular}{|c|c|c|c|c|c|}
\hline No & Name Sine & Lerpunder & Laturide & $\begin{array}{l}\text { Suppon Height } \\
\text { (meter) }\end{array}$ & $\begin{array}{l}\text { Arnsuth } \\
\text { (c, B.vi) }\end{array}$ \\
\hline 1 & Site_1 & -1241513 & 116.835996 & 30 & $0,120,240$ \\
\hline 2 & Site. 2 & -1.225700 & 116344734 & 30 & 0.120 .240 \\
\hline 3 & Site 3 & -1212949 & 116.958935 & 30 & 0.120 .240 \\
\hline 4 & Site_-4 & -1.205411 & 116876.107 & 30 & $0.120,240$ \\
\hline 5 & Site 5 & -1.189802 & 116854.999 & 30 & 0.120 .240 \\
\hline 6 & Site_6 & -1.171408 & 116.880 .222 & 30 & $0,120,240$ \\
\hline 7 & Site_? & -1.153287 & 116.877 .683 & 30 & $0.120,240$ \\
\hline 8 & Site_s & -1.133694 & 116.881 .836 & 30 & $0,120,240$ \\
\hline 9 & Site_e & -1.117586 & 116.882 .483 & 30 & $0,120,240$ \\
\hline 10 & Site__10 & -1.102766 & 116.893 .352 & 30 & $0,120,240$ \\
\hline 11 & Site_11 & -1.090234 & 116907.473 & 30 & $0,120.240$ \\
\hline 12 & Sitt__12 & -1.088085 & 116.914 .990 & 30 & $0,120,240$ \\
\hline 13 & Site 13 & -1.228983 & 116.834 .423 & 30 & $0,120,240$ \\
\hline 14 & Site_14 & -1.214376 & 116.845 .459 & 30 & $0.120,240$ \\
\hline 15 & Site_15 & -1.201631 & 116.856 .041 & 30 & $0.120,240$ \\
\hline 16 & Site_16 & -1.193455 & 116.845 .311 & 30 & $0,120,240$ \\
\hline 17 & Site_17 & -1.175122 & 116.849 .807 & 30 & $0,120,240$ \\
\hline 18 & Site__18 & -1.167128 & 116.866 .153 & 30 & $0,120,240$ \\
\hline 19 & Site_19 & -1.174756 & 116.903 .317 & 30 & $0,120,240$ \\
\hline 20 & Site 20 & -1.174067 & 116.924 .925 & 30 & $0,120,240$ \\
\hline 21 & Sitt__21 & -1.109812 & 116.903 .870 & 30 & $0,120,240$ \\
\hline 22 & Site__22 & -1.254339 & 116.838 .380 & 30 & $0,120,240$ \\
\hline 23 & Site_23 & -1.265621 & 116.837 .327 & 30 & $0,120,240$ \\
\hline 24 & Site 24 & -1.274605 & 1168379080 & 30 & $0,120,240$ \\
\hline 25 & Site_25 & -1.244486 & 116.825 .809 & 30 & $0,120,240$ \\
\hline 26 & Site_26 & -1.244103 & 116.815 .965 & 30 & $0,120,240$ \\
\hline 27 & Site. 27 & -1.252638 & 116.815 .880 & 30 & $0,120,240$ \\
\hline 28 & Site. 28 & -1245903 & 116.822 .611 & 30 & $0.120,240$ \\
\hline 29 & Sitse_29 & -1244466 & 116.844 .648 & 30 & $0,120,240$ \\
\hline 30 & Site. 30 & -1.243616 & 1168554.494 & 30 & $0,120,240$ \\
\hline 31 & Sitt__31 & -1249033 & 116.846 .865 & 30 & $0,120,240$ \\
\hline 32 & Site 32 & -1246949 & 116856.176 & 30 & 0.120 .240 \\
\hline 33 & Site _.33 & -1.260590 & 116.8539 .903 & 30 & $0,120,240$ \\
\hline 34 & Site 34 & -1.254354 & 116.830 .471 & 30 & $0,120,240$ \\
\hline 35 & Site. 35 & -1246722 & 116.826 .731 & 30 & 0.120 .240 \\
\hline 36 & Sitie. 36 & -1247168 & 116.846 .191 & 30 & 0.120 .240 \\
\hline 37 & Site 37 & -1257958 & 116.834 .505 & 30 & $0,120,240$ \\
\hline 38 & Site -38 & -1268427 & 116.841 .973 & 30 & 0.120 .240 \\
\hline 39 & Sinte-39 & -1240710 & 116.817 .768 & 30 & $0,120,240$ \\
\hline 40 & Sitie 40 & -1256922 & 116.823 .344 & 30 & $0.120,240$ \\
\hline 41 & Sinte 41 & -1260532 & 116.834 .677 & 30 & $0.120,240$ \\
\hline 42 & Site_42 & -1263021 & 116.841 .458 & 30 & $0,120,240$ \\
\hline 43 & Site_43 & -1.256163 & 116.819 .999 & 30 & $0,120,240$ \\
\hline 4 & Site_44 & -1.262369 & 116.815 .527 & 30 & $0.120,240$ \\
\hline 45 & Site 45 & -1262084 & 116.817 .369 & 30 & $0,120,240$ \\
\hline 46 & Sitre-46 & -1263074 & 116.826 .123 & 30 & 0.120 .240 \\
\hline 47 & Site.47 & -1263810 & 116.825 .285 & 30 & $0,120,240$ \\
\hline 48 & Sitie 48 & -1263371 & 1168277.724 & 30 & $0,120,240$ \\
\hline 49 & Sint 49 & -1267109 & 116.814 .465 & 30 & $0.120,240$ \\
\hline 30 & Sitit_50 & -1.270379 & 116.810 .581 & 30 & 0.120 .240 \\
\hline 51 & Site__51 & -1.279336 & 116.817 .311 & 30 & $0.120,240$ \\
\hline 52 & Sint__52 & -1277068 & 116.830 .240 & 30 & $0,120,240$ \\
\hline 53 & Sitie 53 & -1265460 & 1168333.446 & 30 & $0,120,240$ \\
\hline 54 & Sitt__54 & -1.268863 & 116.8220 .857 & 30 & $0,120,240$ \\
\hline 35 & Sitie_35 & -1.273016 & 116.848316 & 30 & $0,120,240$ \\
\hline 56 & Sitie_56 & -1265490 & 116.844 .189 & 30 & 0.120 .240 \\
\hline 57 & Site_57 & -1262127 & 116.853 .044 & 30 & $0,120,240$ \\
\hline 58 & Site 58 & -1268211 & 116857.366 & 30 & $0,120,240$ \\
\hline 59 & Site 59 & -1253760 & 116.8585 .539 & 30 & $0.120,240$ \\
\hline 60 & Sinte 60 & -1256163 & 116.867 .808 & 30 & 0.120 .240 \\
\hline 61 & Sinte 61 & -1245998 & 116.871 .047 & 30 & $0.120,240$ \\
\hline 62 & Sitie 62 & -1252687 & 116.865 .877 & 30 & $0.120,240$ \\
\hline 63 & Sinte63 & -1259906 & 116.8599 .897 & 30 & $0,120,240$ \\
\hline 64 & Site_64 & .1239364 & 116.828 .382 & 30 & $0,120,240$ \\
\hline
\end{tabular}




\begin{tabular}{|c|c|c|c|c|c|}
\hline 65 & Site_65 & -1.223557 & 116.811 .159 & 30 & p, 120,240 \\
\hline 66 & Site_66 & -1.206934 & $116.819 .48 \mathrm{~d}$ & 30 & $0,120,240$ \\
\hline 67 & Site_67 & -1.200738 & 116.829 .272 & 30 & $0,120,240$ \\
\hline 68 & Site_68 & -1.191192 & 116.838 .115 & 30 & $0,120,240$ \\
\hline 69 & Site_69 & -1.176096 & 116.841 .270 & 30 & $0,120,240$ \\
\hline 70 & Site_70 & -1.196909 & 116.796 .439 & 30 & $0,120,240$ \\
\hline 71 & Site_71 & -1.185036 & 116.789 .013 & 30 & $0,120,240$ \\
\hline 72 & Site_72 & -1.161686 & 116.789 .727 & 30 & $0,120,240$ \\
\hline 73 & Site_73 & -1.125024 & 116.782 .579 & 30 & $0,120,240$ \\
\hline 74 & Site_74 & -1.106715 & 116.766 .919 & 30 & $0,120,240$ \\
\hline 75 & Site_75 & -1.089324 & $116.743 .44 \mathrm{~d}$ & 30 & $0,120,240$ \\
\hline 76 & Site_76 & -1.075936 & 116.764 .383 & 30 & $0,120,240$ \\
\hline 77 & Site_-77 & -1.050873 & 116.775 .371 & 30 & $0,120,240$ \\
\hline 78 & Site_78 & -1.058768 & 116.800 .092 & 30 & $0,120,240$ \\
\hline 79 & Site_79 & -1.058055 & 116.822 .152 & 30 & $0,120,240$ \\
\hline 80 & Site_80 & -1.055921 & 116.847 .312 & 30 & $0,120,240$ \\
\hline 81 & Site_81 & -1.063702 & 116.869 .355 & 30 & $0,120,240$ \\
\hline 82 & Site_82 & -1.157152 & 116.830 .093 & 30 & $0,120,240$ \\
\hline 83 & Site_83 & -1.097438 & 116.807 .127 & 30 & $0,120,240$ \\
\hline 84 & Site_84 & -1.133604 & 116.814 .511 & 30 & $0,120,240$ \\
\hline 85 & Site_85 & -1.251901 & 116.931 .477 & 30 & $0,120,240$ \\
\hline 86 & Site_86 & -1.243309 & 116.942 .217 & 30 & $0,120,240$ \\
\hline 87 & Site_87 & -1.235177 & 116.953 .206 & 30 & $0,120,240$ \\
\hline 88 & Site_88 & -1.225749 & 116.962 .765 & 30 & $0,120,240$ \\
\hline 89 & Site_89 & -1.215613 & 116.971 .646 & 30 & $0,120,240$ \\
\hline 90 & Site_90 & -1.203918 & 116.979 .302 & 30 & $0,120,240$ \\
\hline 91 & Site_91 & -1.194135 & $116.989 .73 \mathrm{~s}$ & 30 & $0,120,240$ \\
\hline 92 & Site_92 & -1.183677 & 116.999 .262 & 30 & $0,120,240$ \\
\hline 93 & Site_93 & -1.168788 & 117.002 .650 & 30 & $0,120,240$ \\
\hline 94 & Site_94 & -1.154769 & 117.005 .289 & 30 & $0,120,240$ \\
\hline 95 & Site_95 & -1.142428 & 116.999 .559 & 30 & $0,120,240$ \\
\hline 96 & Site_96 & -1.131922 & 116.997 .049 & 30 & $0,120,240$ \\
\hline 97 & Site_97 & -1.233703 & 116.924 .431 & 30 & $0,120,240$ \\
\hline 98 & Site_98 & -1.214651 & $116.913 .78 \mathrm{~s}$ & 30 & $0,120,240$ \\
\hline 99 & Site_99 & -1.196801 & 116.924 .432 & 30 & $0,120,240$ \\
\hline 100 & Site__100 & -1.210017 & 116.942 .450 & 30 & $0,120,240$ \\
\hline 101 & Site_101 & -1.209502 & 116.942 .628 & 30 & $0,120,240$ \\
\hline 102 & Site_102 & -1.162605 & 116.925 .837 & 30 & $0,120,240$ \\
\hline 103 & Site_103 & -1.133760 & 116.934 .742 & 30 & $0,120,240$ \\
\hline 104 & Site_104 & -1.110988 & 116.943 .143 & 30 & $0,120,240$ \\
\hline 105 & Site_105 & -1.149432 & 116.954 .473 & 30 & $0,120,240$ \\
\hline 106 & Site_106 & -1.273644 & 116.860 .773 & 30 & $0,120,240$ \\
\hline 107 & Site_107 & -1.273536 & 116.875 .505 & 30 & $0,120,240$ \\
\hline 108 & Site_108 & -1.264878 & 116.885 .558 & 30 & $0,120,240$ \\
\hline 109 & Site_109 & -1.258988 & 116.915 .953 & 30 & $0,120,240$ \\
\hline 110 & Site_110 & -1.252255 & 116.929 .325 & 30 & $0,120,240$ \\
\hline 111 & Site_111 & -1.250452 & 116.871 .985 & 30 & $0,120,240$ \\
\hline 112 & Site_112 & -1.251139 & 116.885 .890 & 30 & $0,120,240$ \\
\hline 113 & Site_113 & -1.238782 & 116.875 .161 & 30 & $0,120,240$ \\
\hline 114 & Site_114 & -1.222650 & 116.885 .203 & 30 & $0,120,240$ \\
\hline 115 & Site_115 & -1.237838 & 116.901 .597 & 30 & $0,120,240$ \\
\hline 116 & Site_116 & -1.247653 & 116.909 .827 & 30 & $0,120,240$ \\
\hline 117 & Site_117 & -1.211408 & 116.901 .340 & 30 & $0,120,240$ \\
\hline 118 & Site_118 & -1.224451 & 116.906 .490 & 30 & $0,120,240$ \\
\hline 119 & Site_119 & -1.235692 & 116.919 .881 & 30 & $0,120,240$ \\
\hline 120 & Sito_120 & -1.246677 & 116.927 .264 & 30 & $0,120,240$ \\
\hline 121 & Site__121 & -1.266446 & 116.897 .322 & 30 & $0,120,240$ \\
\hline 122 & Site__122 & -1.255901 & 116.905 .117 & 30 & $0,120,240$ \\
\hline 123 & Site_123 & -1.256305 & 116.881 .003 & 30 & $0,120,240$ \\
\hline 124 & Site_124 & -1.246487 & 116.899 .983 & 30 & $0,120,240$ \\
\hline 125 & Site_125 & -1.238782 & 116.906 .748 & 30 & $0,120,240$ \\
\hline 12 & 1 & -1.269760 & . & 30 & $0,120,240$ \\
\hline
\end{tabular}

Pada penelitian ini dilakukan pengaturan jenis antenna yang digunakan, ketinggian antenna, azimuth untuk keperluan mendapatkkan hasil prediksi luas jangkauan wilayah dari penempatanpenempatan 126 e Node B. Untuk penelitian ini digunakan:
Antenna
Height
: 30 meter
Azimuth
: $0,120,240$
Band frekuensi : band 3
Lebar pita
$: 10 \mathrm{MHz}$

: 30deg 18dBi 0Tilt $1800 \mathrm{MHz}$

Berikut hasil plotting site-site E Node B

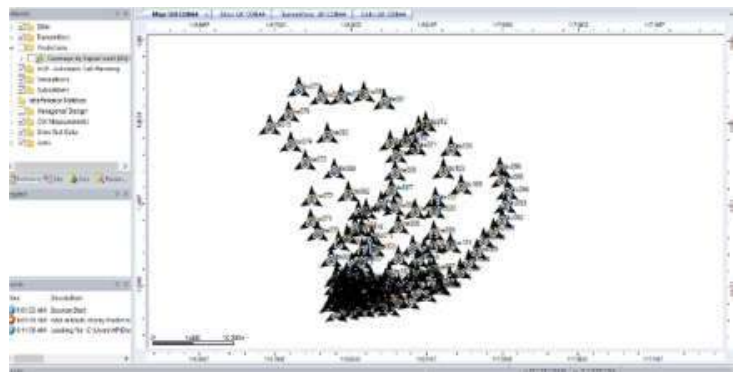

Gambar 4. E Node B kota Balikpapan

Berikut hasil coverage area untuk wilayah Balikpapan yang meliputi 6 kecamatan:

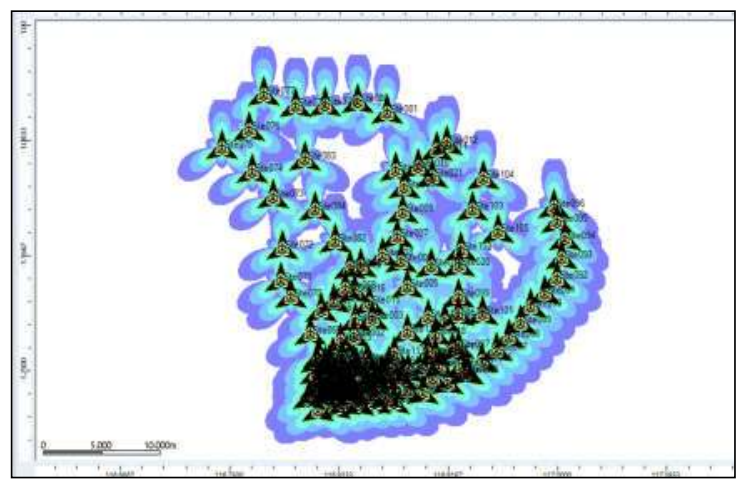

Gambar 5. Hasil Coverage Area E Node B

Dan berikut Generate Report dari hasil prediksi coverage area e Node B

\begin{tabular}{|c|l|l|}
\hline Name & Surface $\left(\mathrm{km}^{2}\right)$ & $\%$ of Covered Area \\
\hline Coverage by Signal Level $(\mathrm{DL}) 1$ Band3 $30 \mathrm{~m}$ & 706,608 & 100 \\
\hline Best Signal Level $(\mathrm{dBm})>=-70$ & 18,578 & 2,629 \\
\hline Best Signal Level $(\mathrm{dBm})>=-75$ & 41,755 & 5,909 \\
\hline Best Signal Level $(\mathrm{dBm})>=-80$ & 81,73 & 11,567 \\
\hline Best Signal Level $(\mathrm{dBm})>=-85$ & 147,615 & 20,891 \\
\hline Best Signal Level $(\mathrm{dBm})>=.90$ & 240,58 & 34,047 \\
\hline Best Signal Level $(\mathrm{dBm})>=-95$ & 369,42 & 52,281 \\
\hline Best Signal Level $(\mathrm{dBm})>=-100$ & 535,898 & 75,841 \\
\hline Best Signal Level $(\mathrm{dBm})>=-105$ & 706,608 & 100 \\
\hline \hline
\end{tabular}

Gambar 6. Generate Report eNode B

Pada hasil Generate Report dapat dilihat bahwa dengan 126 e Node B yang telah diplotting di seluruh wilayah Balikpapan 
telah mencakupi seluruh wilayah 6 kecamatan yang ada di Balikpapan, dimana luas wilayah Balikpapan 503,3 $\mathrm{km}^{2}$ sedangkan dari hasil prediksi perencanaan didapatkan seluas 706,608 $\mathrm{km}^{2}$

Berikut histogram dari dari hasil penelitian dalam satuan wilayah (area):

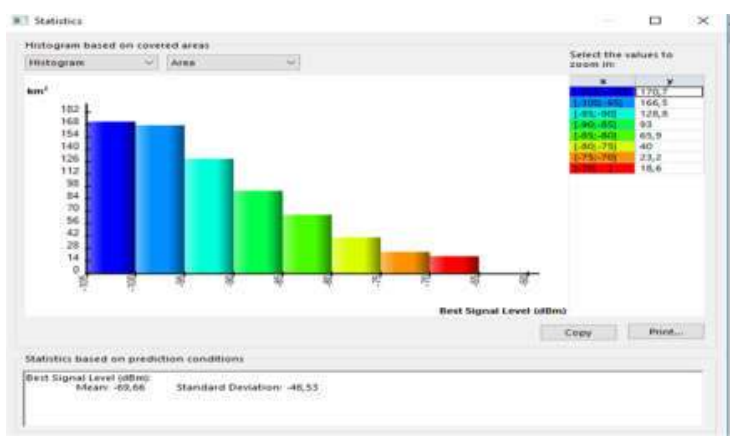

Gambar 7. Histogram (Area)

Untuk kekuatan signal strength (terkuat) $\leq$ $70 \mathrm{dBm}$ indicator warna merah memiliki luasan wilayah sebesar 18,6 km2 sedangkan signal strength (terlemah) antara $-105 \mathrm{dBm},-100 \mathrm{dBm}$ ) indicator warna biru tua memiliki luasan wilayah $170,7 \mathrm{~km} 2$ dengan nilai rata-rata (mean) best signal level sebesar $-69.66 \mathrm{dBm}$.Hasil perencaanaan coverage area jaringan $4 \mathrm{G}$ LTE untuk kota Balikpapan bisa ditampilkan pada google earth sebagai berikut:

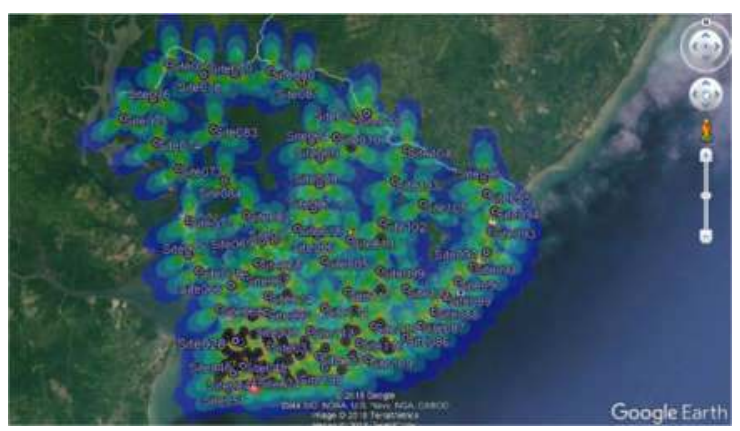

Gambar 8. Tampilan Google Earth

Untuk memaksimalkan coverage area dari perancangan jaringan 4G LTE di atas maka dilakukan upaya optimasi dengan melakukan beberapa penyesuaian nilai parameter dari beberapa eNode B antara lain:

Tabel 6. Optimasi parameter e Node B

\begin{tabular}{|c|c|c|c|c|c|}
\hline No & Name & \multicolumn{2}{|c|}{ Support Height (m) } & \multicolumn{2}{|c|}{ Azimuth } \\
& \multirow{2}{*}{ Site } & \multicolumn{2}{|c|}{ Sesudah } \\
\cline { 3 - 6 } & & Sebelum & Sesudah & Sebelum & \\
\hline 1 & Site_004 & 30, & 30, & $0,120,240$ & $0,150,270$ \\
& & 30,30 & 30,40 & & \\
\hline 2 & Site_079 & 30, & $40,40,40$ & $0,120,240$ & $0,150,240$ \\
& & 30,30 & & & \\
\hline 3 & Site_080 & 30, & 30, & $0,120,240$ & $0,150,240$ \\
& & 30,30 & 30,30 & & \\
\hline 4 & Site_081 & 30, & 30, & $0,120,240$ & $0,120,240$ \\
& & 30,30 & 30,40 & & \\
\hline 5 & Site_083 & 30, & $40,40,40$ & $0,120,240$ & $0,120,240$ \\
& & 30,30 & & & \\
\hline 6 & Site_084 & 30, & $40,40,40$ & $0,120,240$ & $0,120,240$ \\
& & 30,30 & & & \\
\hline
\end{tabular}

Setelah melakukan optimasi dari jaringan maka dilakukan kembali simulasi prediksi coverage area jaringan 4G LTE dan gambar di bawah ini memperlihatkan hasil simulasi optimasi:

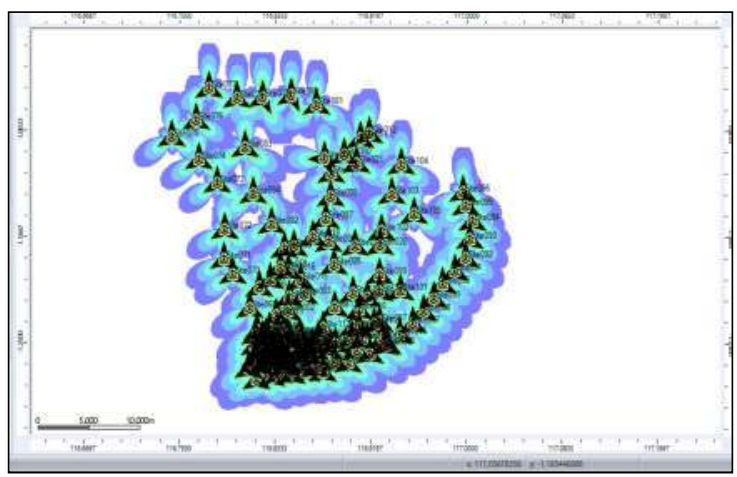

Gambar 9. Hasil optimasi coverage area e Node B

Hasil perencaanaan coverage area jaringan 4G LTE untuk kota Balikpapan yang telah di optimasi bisa ditampilkan pada google earth sebagai berikut: 


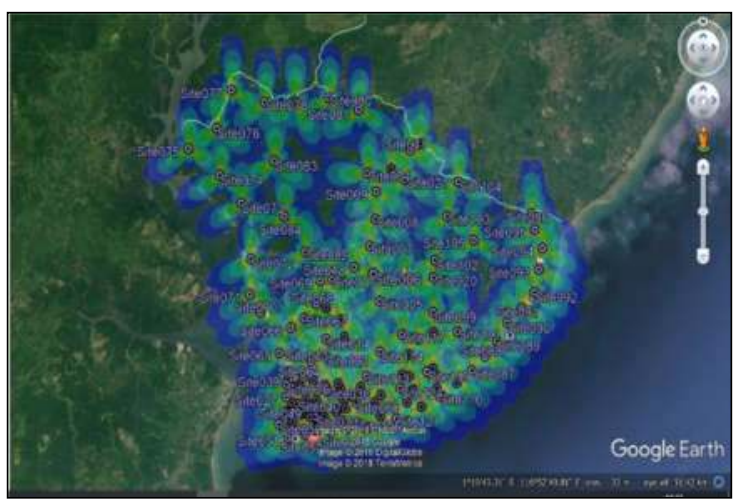

Gambar 10. Tampilan Google Earth Optimasi

Berikut hasil perbandingan coverage area sebelum optimasi dan sesudah optimasi

\begin{tabular}{|c|c|}
\hline Corerage Area sebelum Optimasi & Corerage Area sesudah Optimasi \\
\hline 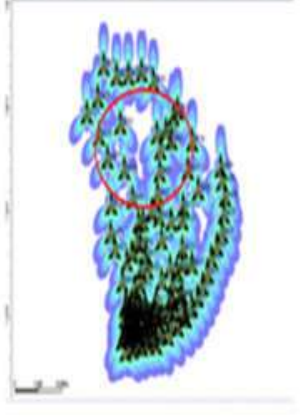 & 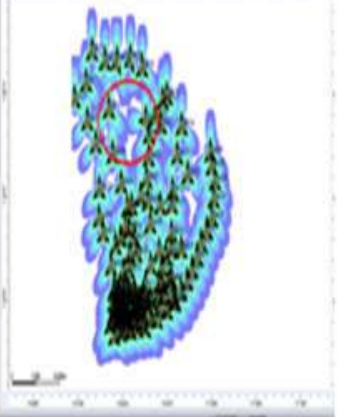 \\
\hline
\end{tabular}

Gambar 11. Perbandingan coverage area

Berikut hasil perbandingan tampilan google earth sebelum optimasi dan sesudah optimasi.

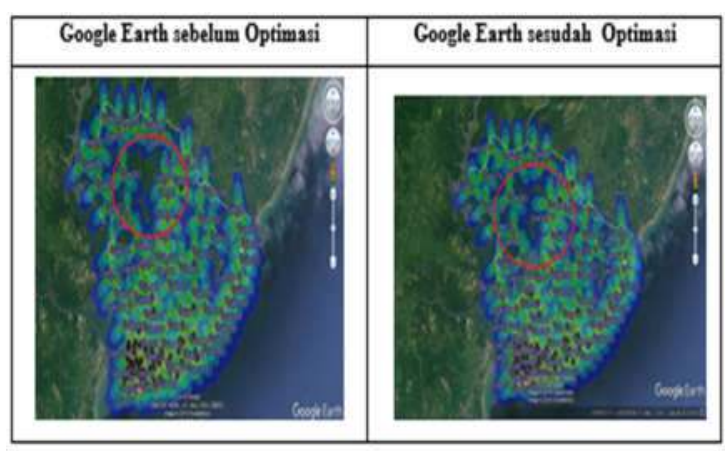

Gambar 12. Perbandingan Google Earth
Dari optimasi yang dilakukan pada penelitian ini terlihat adanya penambahan coverage area dari jaringan 4G LTE yang ada pada kota Balikpapan (pada area yang dilingkari merah). Upaya optimasi ini dilakukan dengan tujuan agar pengguna (user) dapat lebih maksimal dalam menikmati layanan jaringan 4G LTE yang ada di kota Balikpapan. Berikut perbandingan generate report.

Tabel 7. Perbandingan Generate Report

\begin{tabular}{|c|c|c|c|c|c|}
\hline \multicolumn{3}{|c|}{ Generate Report Sebelum Optimasi } & \multicolumn{3}{|c|}{ Generate Report Sesudah Optimasi } \\
\hline $\ln$ & statent & Salcued ta & 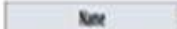 & Sotatent & stcoen he \\
\hline 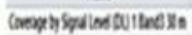 & mia & w & conplasedind bu wer & 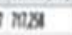 & w \\
\hline letsioustenting & 29 & 20 & letyoulnestung & wo & 29 \\
\hline letipuioditans & cys & is & letsyinestens & fü & 54 \\
\hline letipuastand & ns & $\pi x$ & letiguind fan not & QRS & ifa \\
\hline 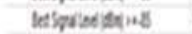 & ees & 25 & letsponstans & 수용 & 25 \\
\hline 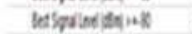 & xy & $4 x$ & bespoundank & 20is & ne \\
\hline 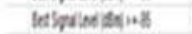 & Xe & QI & letsonint ats in if & 28. & 285 \\
\hline Ietipianestious & gen & $7 x$ & letigilnd tand & $\sqrt{4} \mathbb{N}^{2}$ & $\mathrm{xes}$ \\
\hline Dietiquedentios & $x \equiv$ & Ix & 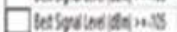 & $n \pi s$ & 10 \\
\hline
\end{tabular}

Dari tabel 7 terlihat adanya penambahan coverage area yang dicakup oleh layanan jaringan 4G LTE network setelah dioptimasi dari 706,608 km2 menjadi $717,258 \mathrm{~km} 2$

Untuk perencanaan coverage area jaringan 4G LTE setelah optimasi dapat dilihat:

1. Nilai parameter RSSI atau best signal level sebagai berikut:

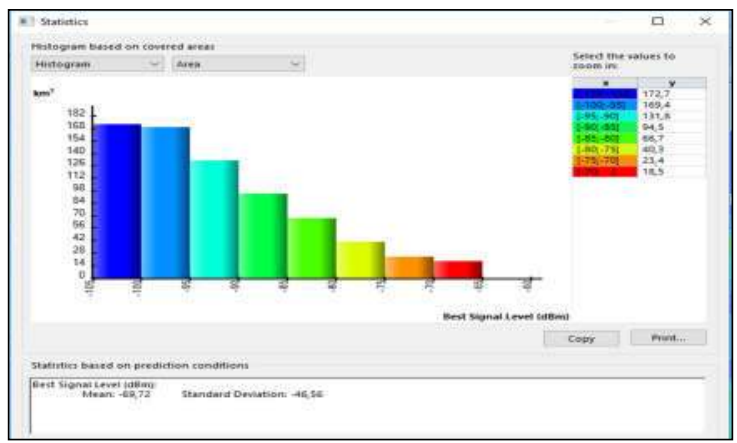

Gambar 13. Hasil simulasi RSSI

Dari hasil simulasi jaringan 4G LTE untuk kota Balikpapan terlihat rata-rata nilai best 
signal level adalah $-69,72 \mathrm{dBm}$ sesuai dengan tabel 2.2 termasuk dalam kategori excellent

\section{Nilai $\mathrm{C} /(\mathrm{N}+\mathrm{I})$}

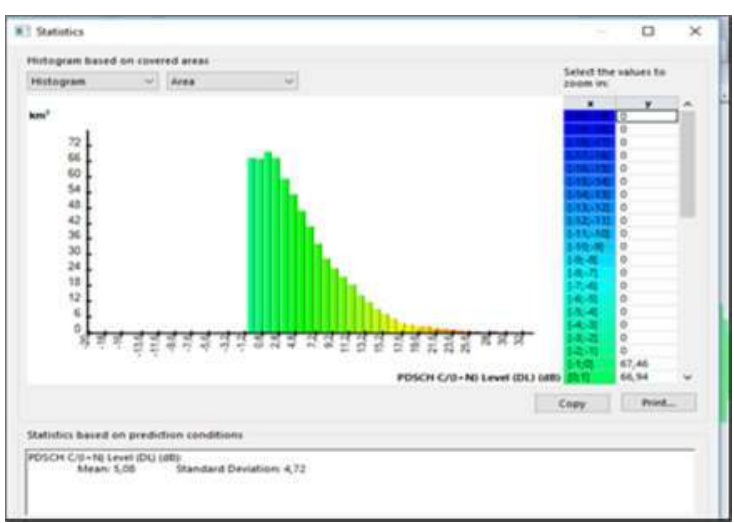

Gambar 14. Hasil simulasi C/ $(\mathrm{N}+\mathrm{I})$

Dari hasil simulasi jaringan 4G LTE untuk kota Balikpapan terlihat rata-rata nilai $\mathrm{C}$ $/(\mathrm{N}+\mathrm{I})$ adalah $5.08 \mathrm{~dB}$ sesuai dengan tabel 2.3 termasuk dalam kategori good. Hal ini menunjukan bahwa perbandingan sinyal utama dengan interferensi dan noise dalam kondisi baik.

\section{Nilai Throughput}

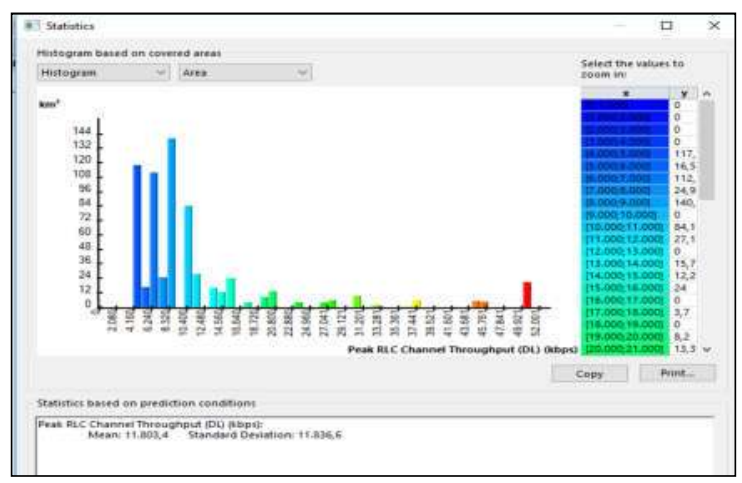

Gambar 14. Hasil simulasi Throughput
4. Nilai RSRP (Reference Signal Received Power)

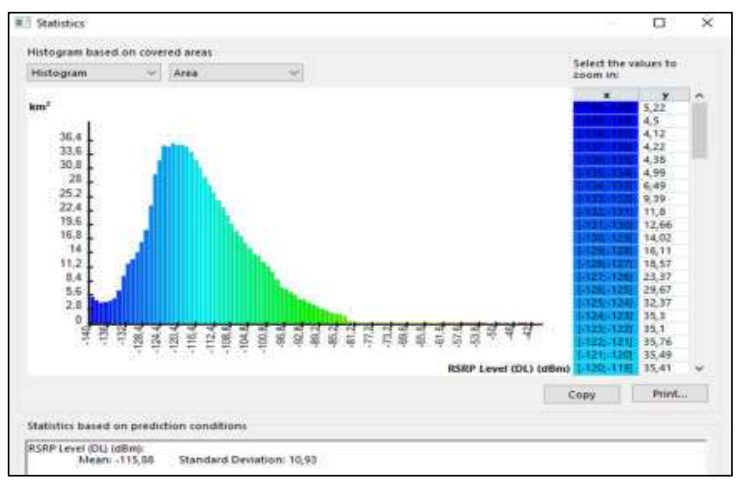

Gambar 15. Hasil simulasi RSRP

Dari hasil simulasi terlihat nilai rata-rata sinyal LTE power yang diterima oleh user sebesar $-115,88 \mathrm{dBm}$ yang masih termasuk dalam kategori fair atau normal

\section{Nilai BLER}

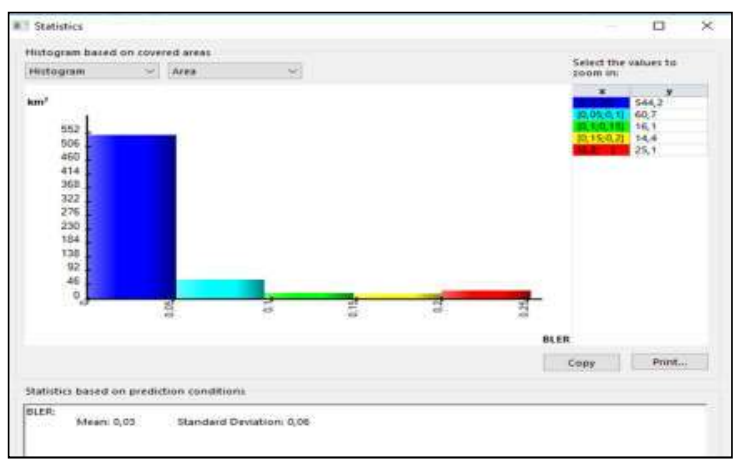

Gambar 16. Hasil simulasi BLER

Dari hasil simulasi terlihat perbandingan total eror blok dengan total blok (BLER) masih pada range baik karena bernilai 0,03 .

\section{KESIMPULAN}

Dari uraian pembahasan yang dibuat, dapat disimpulkan bahwa:

1. Dengan penempatan 126 e Node B jaringan 4G LTE telah dapat menjangkau wilayah kota Balikpapan baik sebelum dan sesudah dilakukan optimasi. 
2. Area jangkauan (coverage are) perencanaan jaringan $4 \mathrm{G}$ LTE sebelum optimasi adalah seluas $706,608 \mathrm{~km} 2$ dan setelah optimasi menjadi 717,258 km2 dengan peningkatan area seluas $10,65 \mathrm{~km}^{2}$

3. Parameter best signal level memiliki nilai rata-rata sebesar $-69,72 \mathrm{dBm}$, termasuk kategori excellent.

4. Parameter $\mathrm{C} /(\mathrm{N}+\mathrm{I})$ memiliki nilai ratarata sebesar 5,08 dB, termasuk kategori good.

5. Parameter throughput memiliki nilai rata-rata sebesar $11.803,4 \mathrm{kbps}$

6. Parameter RSRP memiliki nilai ratarata sebesar $-115,88 \mathrm{dBm}$, termasuk kategori fair atau normal

7. Parameter BLER memiliki nilai ratarata sebesar 0,03 termasuk kategori baik

\section{DAFTAR PUSTAKA}

[1] Adisti.Syafa, Ulfah.Maria, (2016), Perencanaan Jumlah e Node B untuk Jaringan 4G LTE di kecamatan Balikpapan Barat menggunakan Atoll Versi 3.3, Politeknik Negeri Balikpapan

[2] Forsk , (2009), : Atoll RF Planning \& Optimisation Software, U.S : Forsk U.S

Patent and Trademark Office. 1-18

[3] Industrial Networking Solutions Tips and Tricks: Making Sense of Signal Strength/Signal Quality Readings for Cellular Modems

[4] Nurhasanah. Rizka, Analisis Perencanaan Layanan Data Di Jaringan LTE Pada Ruas Tol Cawang - Cikarang Utama Menggunakan Metode Adaptive Soft Frequency Reuse
[5] Sekar.Maharani., Ulfah.Maria, (2016), "Perencanaan Jumlah e Node B Jaringan 4G LTE di Kecamatan Balikpapan Timur", Politeknik Negeri Balikpapan

[6] Ulfah. Maria, (2016), “Analisis Jumlah e Node B LTE untuk kota Balikpapan", Jurnal Sains Terapan. Politeknik Negeri Balikpapan Vol 2 No.1 halaman 56-59.

[7] Wardhana.Lingga, dkk, (2014), 4G Handbook Edisi Bahasa Indonesia, www.nulisbuku.com, Jakarta 